\title{
Michaє Koszowski
}

\section{Elektrownie wiatrowe a inwestycje celu publicznego}

22 grudnia 2011 roku Ministerstwo Gospodarki zaprezentowało pakiet trzech ustaw: nowe Prawo energetyczne, Prawo gazowe i Ustawę o odnawialnych źródłach energii (dalej: ustawa o OZE). W szczególności z ostatnim aktem prawnym wiązane są duże nadzieje, ale i obawy. Ustawa wpisuje się w długoletnią dyskusję nad modelem wsparcia i miejscem odnawialnych źródeł energii w polskim systemie prawa. W szczególności wiele uwagi zajmuje tu priorytetowość inwestycji w odnawialne źródła energii i ich relacji do kwestii finansowych oraz własnościowych. Warto w tym miejscu zwrócić uwagę na projekt komisji sejmowej Przyjazne Państwo, w którym chciano uznania farm wiatrowych (obiektów związanych z wytwarzaniem i dostarczaniem energii elektrycznej) wprost za inwestycje celu publicznego. Wywołało to niemały opór ${ }^{1}$ i ostatecznie nie weszło w życie. Teraz, w związku z projektem ustawy o OZE, która ma być implementacją Dyrektywy Parlamentu Europejskiego i Rady 2009/28/WE z dnia 23 kwietnia 2009 roku 2009/29/WE w sprawie promowania stosowania energii ze źródeł odnawialnych, zmieniającą i w następstwie uchylającą dyrektywy 2001/77/WE oraz 2003/30/WE (dalej: Dyrektywa 2009/29/WE), znów rozgorzał spór dotyczący możliwości uznawania farm wiatrowych za inwestycje celu publicznego. Celem niniejszego opracowania są: podsumowanie dotychczasowego dorobku literatury i orzecznictwa $\mathrm{w}$ tym zakresie oraz odniesienie go do danych technicznych dotyczących energetyki wiatrowej. Dopiero taka perspektywa daje możliwość jednoznacznej oceny tego zagadnienia.

1 A. Jaraszek, Wtaściciele nieruchomości mogq stracić dziatki pod budowę farm wiatrowych, „Dziennik Gazeta Prawna”, <http://prawo.gazetaprawna.pl/artykuly/434667,wlasciciele_nieruchomosci_ moga_stracic_dzialki_pod_budowe_farm_wiatrowych.html >. 
204 | Przegląd Prawniczy Uniwersytetu im. Adama Mickiewicza

\section{Cel publiczny}

Mówiąc o celu publicznym, należy odnieść się do art. 6 Ustawy o gospodarce nieruchomościami (dalej: u.g.n.) z dnia 21 sierpnia 1997 roku$^{2}$. Przepis ten kształtuje pojęcie celu publicznego w formie katalogu działań, czynności lub konkretnych obiektów, które można do niego zaliczyć. Nie wskazuje on żadnych kryteriów uznania danego przedsięwzięcia za cel publiczny. Charakter tego katalogu przysparza zatem pewnych wątpliwości interpretacyjnych - czy stanowi on zbiór zamknięty, czy otwarty? Pewne problemy mogą być związane w szczególności z art. 6 pkt. 10, traktującym o innych celach publicznych określonych w ustawach. Należy tu zgodzić się z wyrokiem Naczelnego Sądu Administracyjnego z dnia 15 maja 2008 roku (II OSK 548/07), który przyjął absolutną niedopuszczalność poszerzenia katalogu celów publicznych w procesie wykładni prawa. Jak zwrócono uwagę w orzeczeniu, w katalogu można znaleźć pewne klauzule generalne, jak klauzula obronności państwa czy bezpieczeństwa publicznego, jednak ich tłumaczenie musi następować w sposób możliwie zawężający, gdyż ratio legis art. 6 Ustawy o gospodarce nieruchomościami jest stworzenie wyraźnie oznaczonej liczby przypadków stosowania terminu „celu publicznego”. Aby mówić o celach publicznych, należy znaleźć cel wyrażony expressis verbis $\mathrm{w}$ art. 6 pkt. 1-9 u.g.n. albo cel określony jako publiczny w innej ustawie (por. wyroki Naczelnego Sądu Administracyjnego z dnia 19 maja 1999 roku, II SA/Wr 1499/98 i z dnia 15 lutego 2000 roku, SA/Bk 901/99). Wojewódzki Sąd Administracyjny w Warszawie w wyroku z dnia 7 marca 2007 roku (IV SA/Wa 2037/06) zwrócił uwagę, iż cel publiczny jako taki, oznacza cel dotyczący ogółu ludzi, służący ogółowi, przeznaczony (dostępny) dla wszystkich. Zastosowanie zasad i trybu przewidzianego dla lokalizacji inwestycji celu publicznego zależy więc od tego, czy zamierzenia inwestycyjne wymagające uzyskania stosownej decyzji posiadają ,pierwiastek publiczny". Zastosowano model definicji w pełni przedmiotowej, bez odwoływania się do podmiotów realizujących dane cele.

Poglądem o ugruntowanej pozycji jest twierdzenie, iż wymienione w u.g.n.i w innych ustawach cele publiczne, w wypadku braku wyraźnych odmiennych regulacji ustawowych, może realizować nie tylko Skarb Państwa oraz jednostki samorządu terytorialnego, ale także inne podmioty (chyba że przepis ustawy stanowi w danej sprawie inaczej). Potwierdzenie tej tezy znaleźć można w stałej ${ }^{3}$ linii orzeczniczej sądów administracyjnych. Warto tu chociażby zwrócić uwagę na Wyrok Naczelnego Sądu Administracyjne-

2 Dz.U. z 1997 r. nr 115, poz. 741.

3 Wyjątkiem jest tu wyrok II SA/Rz 466/07, w którym przyjęto, iż z przymiotu inwestycji celu publicznego mogą korzystać te rodzaje działań wymienionych w art. 6 u.g.n., które realizują jednostki samorządu terytorialnego, bądź państwo realizując swoje zadania obligatoryjne. Dodatkowo, w tym obszarze mogą znaleźć się także jednostki, które na podstawie przepisów szczególnych zostały utworzone przez wskazane jednostki. 
go w Warszawie z dnia 13 marca 2008 roku (II OSK 222/07), który wprost uznał, iż dla klasyfikacji prawnej danej inwestycji do inwestycji celu publicznego nie ma znaczenia, kto finansuje i realizuje daną inwestycję. Jednostką realizującą cel publiczny może być także podmiot prywatny. Podobnie orzekł Naczelny Sąd Administracyjny w wyroku z dnia 9 lutego 2000 roku (I SA 363/99). Również Wojewódzki Sąd Administracyjny w Gliwicach w wyroku z dnia 18 maja 2007 roku (II SA/G1 852/06) uznał, iż okoliczność, że inwestycja ma charakter komercyjny, nie stanowi przeszkody dla uznania tego rodzaju inwestycji za inwestycję celu publicznego.

Nie sposób więc uznać za uzasadniony pogląd, by charakter celów publicznych był związany z publicznoprawnym charakterem podmiotu realizującego. Wiążące jest określenie danego celu jako publicznego we wspomnianym katalogu.

\section{Wywłaszczenie na rzecz inwestycji celu publicznego}

Z zagadnieniem zaliczenia poszczególnych inwestycji do katalogu celów publicznych związana jest dopuszczalność wywłaszczenia w celu ich realizacji. Szczególnie drażliwy jest problem wywłaszczenia na rzecz podmiotu prywatnego.

Dwa fundamentalne akty prawne traktujące o wywłaszczeniu, tj. Konstytucja RP w art. 21 i Europejska Konwencja Praw Człowieka i Obywatela (a dokładniej: art. 1 Pierwszego Protokołu) nie zawierają żadnego przepisu, który wprost zakazywałby wywłaszczenia na rzecz podmiotów prywatnych. W obu aktach ograniczono wymóg dopuszczalności wywłaszczenia do przeprowadzenia go na cel, a nie podmiot publiczny. W związku z tym, w świetle powyższych unormowań możliwe jest wywłaszczenie na rzecz podmiotu prywatnego realizującego cel publiczny.

Polska materia ustawowa ogranicza jednak krąg podmiotów, na rzecz których można dokonać wywłaszczenia. Art. 113 ust. 1 Ustawy o gospodarce nieruchomościami wprost stanowi, iż wywłaszczenia nieruchomości można dokonać wyłącznie na rzecz Skarbu Państwa albo na rzecz jednostki samorządu terytorialnego. Jest to katalog zamknięty, wywłaszczenie na rzecz jakiegokolwiek innego podmiotu będzie jawnym naruszeniem prawa.

Stanowczość tej regulacji jest dalece iluzoryczna. Żaden przepis nie zakazuje Skarbowi Państwa czy jednostce samorządu terytorialnego, na rzecz której wywłaszczono nieruchomość, dalszego rozporządzenia nią, na podstawie różnego rodzaju czynności prawnych, na rzecz innego (w tym prywatnego) podmiotu. Dotyczy to także przeniesienia własności nieruchomości ${ }^{4}$. Na podstawie art. 13 u.g.n. może to nastąpić na podstawie swoistych dla gospodarki nieruchomościami czynności nieodpłatnych. Mowa tu po pierwsze o nieodpłatnym przekazaniu nieruchomości partnerowi lub spółce podmiotu

4 Ustawa o gospodarce nieruchomościami. Komentarz, praca zbiorowa, Warszawa 2011, s. 804. 
publicznego i partnera prywatnego, utworzonej w celu realizacji inwestycji w myśl przepisów o partnerstwie publiczno-prywatnym ${ }^{5}$. Między podmiotami uprawnionymi do dokonywania na ich rzecz wywłaszczeń może dochodzić do darowizn wywłaszczonych nieruchomości na cele publiczne. Wymagane są określenie celu, na jaki nieruchomość jest przekazana, oraz odwołanie darowizny w razie jego niezrealizowania. Warunek powyższy jest o tyle konieczny, iż niezrealizowanie celu publicznego stanowi, zgodnie $z$ art. 136 ust. 3 (w związku z art. 137 ust. 1 u.g.n.), przesłankę do żądania zwrotu nieruchomości wywłaszczonej przez byłych właścicieli. Dla tego typu roszczenia irrelewantne jest, czy nieruchomość pozostaje nadal przy podmiocie, na rzecz którego nastąpiło wywłaszczenie. W takim wypadku nie może zostać wykluczone roszczenie o odszkodowanie z powodu braku możliwości zwrotu nieruchomości w naturze ${ }^{6}$.

Możliwe są wręcz sytuacje, gdy - by zrealizować cel publiczny - niezbędne jest przekazanie go podmiotowi spoza wymienionych w art. 113 ust. 1 u.g.n ${ }^{7}$.

Analiza przepisów u.g.n. jednoznacznie więc wskazuje, iż o ile ustawa literalnie nie dopuszcza możliwości wywłaszczenia nieruchomości na cel publiczny na rzecz podmiotu prywatnego, to można śmiało twierdzić, że de facto to właśnie taki podmiot może łatwo stać się beneficjentem tej instytucji prawnej ${ }^{8}$.

W tym miejscu należy zbadać, jakie cechy inwestycji w elektrownię wiatrową lub ich zespół - farmę wiatrową - mogłyby czynić z niej inwestycję celu publicznego.

\section{Elektrownia wiatrowa jako inwestycja elektroenergetyczna celu publicznego}

Art. 6 pkt. 2 u.g.n. za cel publiczny przyjmuje budowę i utrzymywanie ciągów drenażowych, przewodów i urządzeń służących do przesyłania lub dystrybucji płynów, pary, gazów i energii elektrycznej, a także innych obiektów i urządzeń niezbędnych do korzystania z tych przewodów i urządzeń ${ }^{9}$.

Jednym z pierwszych orzeczeń, w którym polski sąd miał okazję wypowiedzieć się w kwestii oceny elektrowni wiatrowej jako inwestycji celu publicznego na podstawie art. 6 pkt. 2 u.g.n., był wyrok Wojewódzkiego Sądu Administracyjnego w Szczecinie z dnia

5 Dz.U. z 2009 r. nr 19, poz. 100.

6 E. Bończak-Kucharczyk, Ustawa o gospodarce nieruchomościami. Komentarz, Warszawa 2011, s. 599.

7 Artykuł ten między innymi nie uwzględnia możliwości wywłaszczenia nie na rzecz jednostki samorządu terytorialnego, a np. spółki komunalnej.

8 Odmienny pogląd wyraża T. Woś (Wywtaszczanie nieruchomości i ich zwrot, Warszawa 2011, s. 480), który uznaje, iż bezwzględnie nie można dopuścić do przeniesienia własności wywłaszczonej nieruchomości na inny niż publiczny podmiot. W takim wypadku organ ma obowiązek własność lub chociażby władanie nieruchomością przekazać na rzecz Skarbu Państwa lub jednostki samorządu terytorialnego.

9 Pojęcia te zdefiniowane zostały w Dz.U. z 1997 r. nr 54, poz. 348, art. 3 pkt. 11-11g. 
14 sierpnia 2007 roku (II SA/Sz 294/07). W uzasadnieniu prawnym Sąd stwierdził, iż skoro planowana przez skarżącą spółkę inwestycja obejmowała budowę elektrowni wiatrowych, to spółka winna była złożyć do organu I instancji nie wniosek o ustalenie warunków zabudowy, a o ustalenie lokalizacji celu publicznego. Niestety, w orzeczeniu przyjęto to jako pewną tezę, bez jej głębszej analizy czy uargumentowania.

Dokonało tego dopiero Ministerstwo Infrastruktury w specjalnym piśmie, wystosowanym przez Departament Nieruchomości i Planowania Przestrzennego 22 lutego 2008 roku, Zasady lokalizacji elektrowni wiatrowych (BN6ml-023-15/08/566). Ministerstwo poinformowało w nim, iż skoro według przepisów u.g.n. inwestycją celu publicznego jest m.in. budowa i utrzymywanie przewodów i urządzeń służących do przesyłania energii elektrycznej, a także innych obiektów i urządzeń niezbędnych do korzystania $z$ tych przewodów i urządzeń, to za inwestycję celu publicznego należy uznać również budowę turbin wiatrowych, które służą wprowadzeniu energii elektrycznej do publicznej sieci elektroenergetycznej. Sytuacja taka miałaby nie dotyczyć przypadków, gdy energia produkowana jest wyłącznie na potrzeby własne inwestora - wtedy ustalenie warunków zabudowy i zagospodarowania terenu następuje nie w drodze decyzji o lokalizacji inwestycji celu publicznego, a w decyzji o warunkach zabudowy.

Inne stanowisko przyjął Wojewódzki Sąd Administracyjny w Szczecinie w wyroku z 8 maja 2008 roku (II SA/Sz 224/08), w którym nie podzielił stanowiska Samorządowego Kolegium Odwoławczego, że skoro zamiarem inwestora jest budowa elektrowni wiatrowej, która służy wprowadzaniu energii elektrycznej do publicznej, o zasięgu co najmniej lokalnym sieci elektroenergetycznej i ma na celu zapewnienie nieokreślonej liczbie użytkowników dostępu do tych usług, to stanowi ona inwestycję celu publicznego. Dalej Sąd zwrócił uwagę, iż do celów publicznych - w myśl przepisu art. 6 pkt. 2 u.g.n. - zaliczono jedynie urządzenia służące do przesyłania energii elektrycznej, nie zaliczając do nich urządzeń do jej wytwarzania.

Równie krytyczny dla uznania budowy farmy wiatrowej za inwestycję celu publicznego na podstawie art. 6 pkt. 2 u.g.n. był wyrok Wojewódzkiego Sądu Administracyjnego w Krakowie z dnia 30 stycznia 2009 roku (II SA/Kr 735/08). Sąd zakwestionował decyzję wydaną przez organ I instancji w wyniku ponownego rozpoznania sprawy. W jej uzasadnieniu organ wskazał, że z treści wspomnianego artykułu u.g.n. wynika, że celem publicznym jest zarówno budowa i utrzymanie mediów służących do przesyłania, jak obiektów i urządzeń niezbędnych do korzystania z tych mediów. Organ odwoławczy przyjął przy tym, że - aby możliwe było przesyłanie energii elektrycznej - konieczne jest istnienie obiektu lub urządzenia niezbędnego do korzystania $z$ tych sieci. Obiektem takim jest elektrownia, albowiem wynikiem jej pracy jest wytwarzanie energii elektrycznej, która następnie może być przesyłana odpowiednimi urządzeniami przesyłowymi. W świetle powyższych ustaleń, celem publicznym będzie realizacja zarówno w postaci elektrowni konwencjonalnej, jak i elektrowni wykorzystującej np. wiatr 
lub wodę, czyli elektrowni wiatrowej lub wodnej. W ocenie sądu, z brzmienia art. 6 pkt. 2 u.g.n. wprost wynika, że do celów publicznych zaliczono jedynie urządzenia służące do przesyłania energii elektrycznej, nie zaliczając do nich urządzeń do ich wytwarzania. Określone we wskazanym artykule u.g.n. kategorie celów publicznych winny być interpretowane ściśle.

Zdaniem Naczelnego Sądu Administracyjnego, wyrażonym w przytoczonym już wyroku (II OSK 548/07), obecnie tylko budowa i utrzymanie przewodów i urząadzeń służących do przesyłania energii elektrycznej ex definitione stanowi w tym zakresie cel publiczny, a pozostałe zamierzenia inwestycyjne $\mathrm{z}$ tej sfery gospodarki energetycznej do uzyskania takiej kwalifikacji potrzebują wykazania się dodatkową cechą (,niezbędnością do korzystania").

Wojewódzki Sąd Administracyjny w Bydgoszczy, w wyroku z dnia 17 listopada 2009 roku (II SA/Bd 844/09), poszerzył te rozważania, wskazując, iż skoro elektrownia wiatrowa nie została wymieniona wprost $\mathrm{w}$ art. 6 Ustawy o gospodarce nieruchomościami i nie charakteryzuje się ona wspomnianą cechą „niezbędności do korzystania”, nie ma możliwości uznania tej inwestycji za inwestycję celu publicznego. Odmienna interpretacja prowadzilaby do nieuprawnionego wniosku, iż budowa każdej elektrowni stanowi realizację celu publicznego w rozumieniu art. 2 pkt. 5 u.p.z.g. ${ }^{10} \mathrm{i}$ art. 6 u.g.n.

Jak wykazano powyżej, można mówić o dość stabilnej linii orzeczniczej sądów administracyjnych w tym zakresie. Nie sposób odnieść się do niej krytycznie. Zwraca w szczególności uwagę argument „niezbędności” inwestycji. Aby inwestycja w elektrownię wiatrową mogła uzyskać taki przymiot, należałoby przyjąć istnienie obszaru, dla którego tego typu źródło energii byłoby jedynym możliwym do uzyskania, umożliwiającym pracę instalacji przesyłowych lub dystrybucyjnych obiektem. Taka sytuacja, oczywiście, w praktyce jest niemożliwa do uzyskania. Dlatego też należy odrzucić możliwość kwalifikacji elektrowni wiatrowej jako inwestycji celu publicznego na podstawie art. 6 pkt. 2 u.g.n.

\section{Elektrownia wiatrowa jako inwestycja prośrodowiskowa celu publicznego}

\section{Elektrownia wiatrowa w świetle ustawy o gospodarce nieruchomościami i nowej ustawy o OZE}

Drugą przesłanką z katalogu art. 6 u.g.n, którą często próbuje się uzasadniać uznanie elektrowni wiatrowej za inwestycję celu publicznego, jest jej kwalifikacja jej jako służącej ochronie środowiska w rozumieniu pkt. 4 wspomnianego przepisu. Kwestią interpretacji pozostaje, jakie inwestycje mieszczą się w tym katalogu.

Przed przedstawieniem obecnego stanu prawnego, warto zaznaczyć planowane zmia-

10 Dz.U.z 2003 r. nr 80, poz. 717. 
ny związane z wejściem w życiu ustawy o OZE. Zgodnie z art. 97 projektu tej ustawy, zmienione mają zostać przepisy m.in. art. 80 ust. 1 Ustawy dotyczącej oddziaływania na środowisko ${ }^{11}$, poprzez dodanie punktu 5:

Jeżeli była przeprowadzona ocena oddziaływania przedsięwzięcia na środowisko, właściwy organ wydaje decyzję o środowiskowych uwarunkowaniach, biorąc pod uwagę:

$[\ldots]$

5) korzystny wpływ instalacji odnawialnego źródła energii na środowisko, związany z wykorzystywaniem energii z odnawialnych źródeł energii.

Nowelizacja ta wynika $\mathrm{z}$ obowiązku implementacji do prawa polskiego Dyrektywy 2009/28/WE.

Zwolennicy uznawania farm wiatrowych za inwestycje celu publicznego ${ }^{12}$ jako mających na celu ochronę środowiska zwracają w szczególności uwagę na Preambułę implementowanej dyrektywy, która w ich ocenie per se uzasadnia określenie farmy wiatrowej jako inwestycji celu publicznego.

W szczególności zwraca się uwagę na pkt. 42 Preambuły Dyrektywy, stanowiący:

Z uwagi na korzyści płynące z szybkiego zastosowania energii ze źródeł odnawialnych oraz z uwagi na jej zrównoważony charakter i korzystny wpływ na środowisko, państwa członkowskie, stosując przepisy administracyjne, planując struktury i przepisy prawne dotyczące przyznawania pozwoleń na instalacje w odniesieniu do kontroli i redukcji zanieczyszczeń z zakładów przemysłowych, walki z zanieczyszczeniem powietrza oraz zapobiegania przedostawaniu się niebezpiecznych substancji do środowiska lub minimalizacji tego procesu, powinny uwzględnić wkład odnawialnych źródeł energii w realizację celów związanych z ochroną środowiska i zmianami klimatycznymi, zwłaszcza w porównaniu z instalacjami wytwarzającymi energię ze źródeł nieodnawialnych.

Uzupełnia go pkt. 44, dotyczący spraw procedur ocennych:

11 Dz.U. z 2008 r. nr 199, poz. 1227.

12 Stanowisko Fundacji na rzecz Energetyki Zrównoważonej w sprawie możliwości zaliczania dziatań polegajacych na wykorzystaniu odnawialnych źródet energii do kategorii inwestycji celu publicznego po wejsciu w życie Dyrektywy Parlamentu Europejskiego i Rady 2009/28/WE z dnia 23 kwietnia 2009 r. w sprawie promowania stosowania energii ze zródet odnawialnych, <http://www.fnez.org/ upload/file/30.pdf>; K. Lasocki, Projekt ustawy o OZE a kwalifikacja odnawialnego źródta energii jako inwestycji celu publicznego, Centrum Informacji o Rynku Energii, <http://www.cire.pl/ pokaz-pdf-\%252Fpliki\%252F2\%252FLasocki-OZE.pdf>. 
210 | Przegląd Prawniczy Uniwersytetu im. Adama Mickiewicza

Należy zagwarantować spójność między celami niniejszej dyrektywy oraz innym prawodawstwem wspólnotowym dotyczącym ochrony środowiska. W szczególności w trakcie procedur oceny, planowania lub koncesjonowania instalacji wytwarzających energię ze źródeł odnawialnych państwa członkowskie powinny uwzględniać całość prawodawstwa wspólnotowego w zakresie ochrony środowiska, a także udział odnawialnych źródeł energii w spełnianiu celów dotyczących środowiska i zmiany klimatu, zwłaszcza w porównaniu z instalacjami wytwarzającymi energię ze źródeł nieodnawialnych.

W ocenie zwolenników tezy o zaliczeniu elektrowni wiatrowych do inwestycji celu publicznego, dwa powyższe przepisy wprost uznają tego typu instalacje za inwestycje prośrodowiskowe. Należy w tym miejscu przedstawić cechy techniczne elektrowni wiatrowych i ocenić, czy rzeczywiście tego typu inwestycje oddziałują na otoczenie wyłącznie pozytywnie.

\section{Uwarunkowania techniczno-środowiskowe energetyki wiatrowej}

Elektrownie wiatrowe konkurują z energetyką konwencjonalną, opartą na spalaniu węgla czy gazu. Pomijając nakłady energii niezbędne do skonstruowania takiej elektrowni, samo wytworzenie energii (w przypadku elektrowni wiatrowych) nie pociąga za sobą konieczności spalania żadnego rodzaju paliwa. Tym samym mają one niebagatelny wpływ na ograniczanie emisji produktów spalania towarzyszących konwencjonalnym źródłom pozyskiwania energii - dwutlenku węgla, dwutlenku siarki, tlenków azotu i pyłów. To korzystne oddziaływanie na stan zanieczyszczenia atmosfery jest decydujące, jeśli chodzi o uznawanie elektrowni wiatrowych za tzw. czystą energię i objęcie ich zakresem Dyrektywy 2009/28/WE.

Wydaje się, że obecnie w dyskusji nad uznaniem elektrowni wiatrowych za inwestycje celu publicznego w świetle nowej ustawy o OZE zapomina się, iż inwestycje tego typu nie mają bezsprzecznie pozytywnego wpływu na atmosferę. Praca turbin oddziałuje również na przyrodę ożywioną, a fakt ten nie może zostać pominięty w analizie elektrowni wiatrowej jako inwestycji mającej na celu ochronę środowiska.

Hałas generowany przez pracę rotora i śmigieł wiatraka, emitujący energię akustyczną do otoczenia, jest jednym $z$ bardziej odczuwalnych sposobów oddziaływania elektrowni wiatrowej na otoczenie. Moc akustyczna urządzeń jest znaczna, powoduje zmianę klimatu akustycznego na pokaźnych połaciach terenu w sąsiedztwie farmy wiatrowej. Zasięg oddziaływania potęguje jeszcze bardziej usytuowanie części ruchomych wiatraka - usadawia się je przecież na wysokich masztach, sięgających od kilkudziesięciu po czasem i sto metrów. Mając na uwadze małą energię akustyczną, irrelewantny jest hałas generowany przez elementy zagospodarowania otoczenia stacji, takie jak transformatory potrzeb własnych i rozdzielnia. 
Wyniki modelowych obliczeń z różnych terenów Polski dla różnych typów elektrowni i różnej ich liczby wskazują, że izofony o wartościach 40 i 45 dB mogą przebiegać w odległości kilkuset metrów od elektrowni (dla $45 \mathrm{~dB}$ - od 400 do 500 m, dla 40 dB - ok. $800 \mathrm{~m}$, nawet do $1000 \mathrm{~m})^{13}$.

Podłączenie farmy wiatrowej powoduje inną jeszcze formę oddziaływania na otoczenie, jakim jest emisja ponadnormatywnego promieniowania elektromagnetycznego, które może sięgać kilkunastu metrów od jego przewodów ${ }^{14}$. Elektrownie wiatrowe stawia się raczej na terenie otwartym, często na użytkach rolnych, dzięki czemu do oddziaływania pola na ludzi nie dochodzi.

Elektrownia wiatrowa stanowi element obcy w środowisku. Nie jest możliwe, by nie miała ona wpływu na swoje otoczenie. Wśród ekologów podnosi się problem oddziaływania elektrowni wiatrowych na zwierzęta ${ }^{15}$.

Obecność farmy wiatrowej dla zwierząt naziemnych jest raczej irrelewantna. Zmiany populacji zwierząt, do jakich dochodzi w otoczeniu inwestycji, są konsekwencją zmiany w roślinności pokrywającej teren, związanej ze zmianą użytkowania gruntów.

O wiele dotkliwiej odczuwa powstanie farmy wiatrowej na danym terenie awifauna. Oddziaływanie elektrowni na ptaki jest zauważalne zarówno w okresie lęgowym, jak i poza nim.

Może ono polegać na kolizjach z elementami turbiny czy masztu, co zwykle skutkuje śmiercią lub poranieniem lub na zmianach rozmieszczenia i zachowania ptaków - opuszczeniem siedlisk i zmianie tras przelotów, spowodowanych tzw. efektem bariery ${ }^{16}$.

Elektrownie zlokalizowane w sąsiedztwie żerowisk i lęgowisk ptaków, stanowiących tereny ich regularnych przelotów, odnotowują największy odsetek śmiertelności wskutek zderzeń. Istotną zmienną, poza liczebnością ptactwa na danym obszarze, jest również widoczność - większość zderzeń ma miejsce w porze nocnej lub przy złych warunkach pogodowych. Przy dobrej widoczności pracujące turbiny odstraszają ptaki ${ }^{17}$.

Wspomniany efekt odstraszenia powoduje zmniejszenie wykorzystania przez awifaunę w celach żerowania, odpoczynku czy gniazdowania terenów przyległych do farmy wiatrowej. Jest to w pewnym stopniu efekt korzystny, gdyż ma wpływ na zmniejszenie przypadków zderzeń z turbinami. $Z$ drugiej jednak strony, duże inwestycje, których

13 M. Przewoźniak, Oddziatywanie elektrowni wiatrowych na środowisko - zagadnienia sozologiczne, ekologiczne i krajobrazowe, [w:] II Konferencja "Rynek energetyki wiatrowej w Polsce", Warszawa 2007, s. 217.

14 Ibidem, s. 218.

15 Cf. Wytyczne Polskiego Stowarzyszenia Energetyki Wiatrowej w zakresie oceny oddziatywania elektrowni wiatrowych na ptaki, <http://www.psew.pl/files/wytyczne_w_zakresie_oceny_oddzialywania_elektrowni_wiatrowych_na_ptaki_apa_v_10new_okladka_pl.pdf $>$.

16 Wind energy development and Natura 2000 (EU Guidance on wind energy development in accordance with the EU nature legislation), Bruksela 2010, s. 32.

17 M. Przewoźniak, op. cit., s. 219 
efektywność jest o wiele większa, a ekonomiczne uzasadnienie - dużo lepsze, składają się $z$ sieci turbin wiatrowych oddalonych od siebie, rozmieszczonych na znacznym obszarze. Przeciętny zespół elektrowni wiatrowych, składający się z 20 siłowni zlokalizowanych na terenie o kształcie koła o promieniu $1 \mathrm{~km}$, spowoduje zmiany awifauny (głównie jej rozmieszczenia) na powierzchni ok. $1000 \mathrm{ha}$. W przypadku linijnego rozmieszczenia 20 elektrowni co $400 \mathrm{~m}$, powierzchnia zmian awifauny wyniesie ok. $1500 \mathrm{ha}^{18}$. Sytuacja taka może poważnie zmienić trasy przelotów ptaków wędrownych, jak również spowodować utratę siedlisk przez ptaki gniazdujące w sąsiedztwie inwestycji.

\section{Prośrodowiskowy charakter elektrowni wiatrowej w orzecznictwie}

Jak wskazano wyżej, farma wiatrowa potencjalnie może oddziaływać na swoje otoczenie na wiele sposobów. Może to stanowić podstawę do pociągnięcia inwestora do odpowiedzialności za szkodę w środowisku. Podstawowe znaczenie ma tu art. 322 i następne, oraz art. 362 i następne prawa ochrony środowiska ${ }^{19}$, regulujące odpowiednio reguły odpowiedzialności cywilnej i administracyjnej za szkodę w środowisku.

Inwestycja, jaką jest farma wiatrowa, nie ma wyłącznie prośrodowiskowego charakteru, można wręcz wskazać wiele przykładów jej oddziaływań szkodliwych. Trudno więc tutaj kwalifikować ją jako inwestycję celu publicznego $\mathrm{z}$ art. 6 ust. 4 u.g.n.

Orzecznictwo sądów administracyjnych również zwróciło uwagę na te cechy farm wiatrowych, które utrudniają uznanie ich za inwestycje prośrodowiskowe w rozumieniu przepisów u.g.n. Dość gruntownie tę kwestię rozważył Wojewódzki Sąd Administracyjny w Bydgoszczy, w wyroku z dnia 3 listopada 2009 roku (II SA/Bd 714/09), w którym słusznie stwierdził, iż budowa wielu zakładów przemysłowych oraz ich remont czy modernizacja służą ochronie środowiska naturalnego. Zastosowanie nowoczesnych technologii najczęściej sprzyja ochronie środowiska. budowa tak samo w przypadku elektrowni wiatrowych. Nie oznacza to jednak, że każda inwestycja sprzyjająca ochronie środowiska jest inwestycją celu publicznego. Taki walor posiadają tylko przedsięwzięcia enumeratywnie wymienione w przepisie art. 6 Ustawy z dnia 21 sierpnia 1997 roku o gospodarce nieruchomościami. Pojęcie celu publicznego nie jest dowolne i przy jego interpretacji nie jest wystarczające odwołanie się do potocznego rozumienia tego celu. Co już zostało podkreślone wcześniej, katalog celów publicznych ma charakter zamknięty i nie jest możliwe jego rozszerzenie $w$ drodze interpretacji.

W podobnym tonie wypowiedział się ten sam sąd w wyroku z 24 marca 2010 roku (II SA/Bd 33/10) stwierdzając, iż nie można tracić z pola widzenia faktu, że podstawową funkcją elektrowni wiatrowej jest wytwarzanie energii elektrycznej, a inwestor, budując taki obiekt, czyni to w konkretnym celu ekonomicznym, tj. sprzedaży prądu, a nie w celu ochrony środowiska naturalnego. Elektrownia wiatrowa nie jest więc obiektem czy też

18 Ibidem, s. 220.

19 Dz.U.z 2001 r. nr 62, poz. 627. 
urządzeniem służącym stricte ochronie środowiska. Fakt, że proces wytworzenia energii odbywa się przy zastosowaniu technologii przyjaznej środowisku („sprzyjającej ochronie środowiska”) nie może implikować uznania elektrowni wiatrowej za inwestycję głównie jego ochronie służącą.

Można więc śmiało postawić tezę, iż w obecnym stanie prawnym, jak i tym zmodyfikowanym ustawą o OZE, nie sposób uznać farmy wiatrowej za inwestycję celu publicznego ani na podstawie pkt. 2, ani 4 art. 6 u.g.n. U podstaw takiego stanu rzeczy leży nie tyle regulacja prawna, co uwarunkowania techniczne tego typu inwestycji.

\section{Podsumowanie}

Jednym z celów uznania inwestycji za inwestycję celu publicznego jest skrócenie procedur niezbędnych w procesie inwestycyjnym. Wśród organów pierwszej instancji (organów wykonawczych jednostek samorządu terytorialnego) obserwuje się tendencję do uznawania farm wiatrowych za inwestycje celu publicznego. Przynosi to jednak skutek odwrotny do zamierzonego.

W obecnym stanie prawnym nie sposób uznać elektrowni wiatrowej za inwestycję celu publicznego. Również postulaty de lege ferenda w sprawie ewentualnej nowelizacji art. 6 u.g.n. mogłyby być nader nieefektywne. Prima facie, wystarczyłoby dodać do katalogu „inwestycje w bezemisyjne obiekty wytwarzające energię.” Jednak chociaż elektrownia wiatrowa poza zdarzeniami o charakterze wypadku nie wytwarza gazów ani pyłów do atmosfery, nie jest obiektem bezemisyjnym, obojętnym dla środowiska. Hałas i promieniowanie, generowane przez nią, mają niebagatelny wpływ na środowisko, stąd inwestycja tego typu uznawana jest za oddziałującą lub mogącą oddziaływać na środowisko. $Z$ tego względu, mając na uwadze nie tyle ograniczenia prawne, co techniczne uwarunkowania elektrowni wiatrowej, trudno mówić w jej przypadku o inwestycji prośrodowiskowej. Należy, oczywiście, brać pod uwagę brak emisji gazów cieplarnianych przy produkcji energii ze źródeł wiatrowych. Nie można jednak jednocześnie zapominać o naturze takiej inwestycji, która ma pewien niepomijalny negatywny wpływ na środowisko.

$Z$ powyższych względów, mimo odwrotnej tendencji wśród organów pierwszoinstancyjnych, sądownictwo administracyjne przyjmuje względnie jednolitą ocenę tego typu inwestycji. Nowa ustawa o OZE raczej nie ma szans tej linii orzeczniczej zmienić. Stąd, chociaż inwestor, zabiegając o uznanie inwestycji w farmę wiatrową za inwestycję celu publicznego, może o wiele szybciej uzyskać samą decyzję administracyjną pozwalającą mu na budowę, będzie ona obarczona sporym ryzykiem skutecznego wniesienia przeciwko niej protestu. Ten przybierze on postać długotrwałej procedury odwoławczej - administracyjnej i sądowo-administracyjnej. Sytuacja taka skutecznie może zablokować inwestycję na wiele lat. Paradoksalnie więc, w interesie inwestora leży uzyskanie 
decyzji o warunkach zabudowy, a nie decyzji o lokalizacji inwestycji celu publicznego. Uniknie on dzięki temu przedłużenia procesu inwestycyjnego, co jest również w interesie państwa. Nie można zapominać o związaniu Polski celem indykatywnym Dyrektywy 2009/29/WE. W implementacji prawa unijnego, po pierwsze musimy stawiać na jego efektywne praktyczne zastosowanie. Obecna polityka energetyczna Unii Europejskiej czyni wspieranie rozwoju odnawialnych źródeł energii celem strategicznym państw członkowskich. Niekoniecznie jednak musi ono polegać na kwalifikacji wymienionych urządzeń do inwestycji celów publicznych. Obecny stan prawny, a jeszcze bardziej projektowana ustawa o OZE dają w tych kwestiach całą paletę możliwości organom państwa i samorządu terytorialnego.

\section{Summary}

\section{Wind power plants as an investment of a public purpose}

On 22 December 2011, the Ministry of Economy presented a draft law on Renewable Energy Resources (RES), which fits into the discussion on the recognition of wind power plant as an investment of a public purpose (IPP). The author is of an opinion on that a wind power plant cannot be considered as an IPP for legal, rather than technical reasons. The investor's objective is to obtain an outline planning decision, not a decision on the location of an IPP, which might otherwise prolong the investment process.

KeYwords: Renewable energy sources, investment of a public purpose, energy law, environmental protection law 